\title{
Adaptive Livelihood Strategies among Households after the Closure of Fluorspar Mining Company in Keiyo South Sub-County, Elgeyo Marakwet County, Kenya
}

\author{
Finson Kiprop Bargoria, Francis Barasa, Paul Sutter Chebet \\ Department of Sociology, Psychology and Anthropology, Moi University, Kenya
}

Received July 27, 2020; Revised October 16, 2020; Accepted November 12, 2020

\section{Cite This Paper in the following Citation Styles}

(a): [1] Finson Kiprop Bargoria, Francis Barasa, Paul Sutter Chebet, "Adaptive Livelihood Strategies among Households after the Closure of Fluorspar Mining Company in Keiyo South Sub-County, Elgeyo Marakwet County, Kenya," Sociology and Anthropology, Vol. 8, No. 6, pp. 178 - 186, 2020. DOI: 10.13189/sa.2020.080602.

(b): Finson Kiprop Bargoria, Francis Barasa, Paul Sutter Chebet (2020). Adaptive Livelihood Strategies among Households after the Closure of Fluorspar Mining Company in Keiyo South Sub-County, Elgeyo Marakwet County, Kenya. Sociology and Anthropology, 8(6), 178 - 186. DOI: 10.13189/sa.2020.080602.

Copyright $\bigcirc 2020$ by authors, all rights reserved. Authors agree that this article remains permanently open access under the terms of the Creative Commons Attribution License 4.0 International License

\begin{abstract}
The establishment and existence of the Fluorspar Mining Company created direct and indirect employment opportunities for the local population. However, the closure of mining activities within the mining area may have led to social and economic challenges for the local communities. The study objective was to analyze the livelihood strategies among households in Keiyo South Sub-county Elgeyo Marakwet County Kenya. The theory informed the study of Redefinition of situation. Survey research design guided the study. The target population was all the households' heads in the study area. The sample size was 254 respondents. A multistage sampling technique was used. Data collection methods included questionnaires, interviews, and observation and focus group discussions. Quantitative data collected were analyzed using frequencies and percentages and presented in the form of matrix tables. Qualitative data were analyzed thematically. The results of the study show that mining is a major propellant of economic activities in most mining areas by creating wealth, providing jobs, and stimulating business ventures for community members. Further, closure of the company acted as a major economic setback to the community as a whole. The study findings also show that majority $91(44.4 \%)$ of respondents earned an income of 4001-8000ksh while minority 7(3.4\%) earned an income of between 0-500kshs. The average income per month after closure was too low since their main source of income was lost, leaving them in despair. Communities and
\end{abstract}

mineworkers should be involved in planning for company closure and all other matters that affect their livelihoods.

Keywords Adaptive Livelihood, Strategies, Households' Closure of Fluorspar Mining Company

\section{Introduction}

Globally, livelihood assurances and sustainability are key to human survival. However, any destruction of livelihood is likely to lead to serious psychological, social, physical suffering and even death. It becomes even worse when policy intervention is not put in place in time. Despite the impressive contribution of the mining sector to national government revenue, foreign reserves and other infrastructural development, many stakeholders still argue that the adverse effects of mining erode the benefits of mining Assan and Muhammed [1].

Livelihoods of rural households are diverse across regions and countries and within countries. While some rural households rely primarily on one type of activity, most people now seek to diversify their livelihood base as a way to reduce risk. In North America, raw mineral production is valued at approximately US\$ 70 billion. The industry employs approximately 1 million people Plumpton [2]. In Peru, the mining sector accounts for 50\% of the country's annual export earnings. The mining 
industry's contribution to the Peruvian economy is represented by $\$ 240 \mathrm{~m}$ paid in taxes; $\$ 400 \mathrm{~m}$ spent on local purchases; $\$ 280 \mathrm{~m}$ in imported goods and accounted for over 11\% of GDP (Pierola, Fernandes and Farole [3]. In Sweden, mining companies and the surrounding mining communities face a broad range of practical challenges that provide both possibilities and obstacles when it comes to socially sustainable development Abrahamsson et al. [4]. The mining companies and communities in Sweden, to varying degrees, share these challenges with mining companies and communities in Australia, Canada, and several other similar countries. For example, mining often takes place in rural districts where regional growth depends on mining (as well as forestry and steel) Fleming and Measham [5].

In Africa, mining is a major economic activity in many Sub-Saharan countries Andriamasinoroand Angel [6]. However, mining as an industrial activity takes place in the natural environment, problematic areas around where it occurs. Assan and Muhammed [1] indicated that the livelihoods of mining communities in developing countries are structured around an assortment of agricultural activities and complementary subsistence occupations whose impact on the environment is negligible compared to mining operations. However, when mining companies displace these companies, they attempt to diversify the economy of the local people which is often unsuccessful because of lack of the requisite capacity among the indigenous people to take advantage of the formal employment opportunities resulting from the mining operations. Even though the mining sector reforms have contributed tremendously to macro-economic gains, the associated growth has had detrimental impacts on indigenous communities such as land degradation, contamination, and chemical pollution Ofosu-Mensah [7].

Livelihoods and quality of life of the rural dwellers in Sub-Saharan Africa are affected or even controlled by a multiplicity of factors or contexts that make a life for them almost a struggle for survival Mensah [8]. These factors border on economic policies, agro-climate, environment, socio-culture, demography, infrastructure, services, governance and so forth. In South Africa, where gold is the largest mineral foreign income earner, gold mining alone contributes $27.4 \%$ in mineral revenues.

In Kenya, the establishment and existence of the mining companies create direct and indirect employment opportunities for the local population and generates prospects for starting new businesses and expanding existing ones further contributing to both poverty reduction and economic growth by enriching livelihoods. Moreover, mining projects provides livelihood assurances and develops basic infrastructure facilities such as schools, dispensaries and recreational facilities, among others in the mining areas, thus replacing social dimensions of households. However, closure of fluorspar mining activities in the year 2016 which used to produce substantial tonnes of fluorspar mineral for export has led to social and economic challenges to local communities resulting in widespread unemployment, poor nutrition, high crime rates and increased dependency. Besides, there is need therefore to understand livelihood strategies among the communities affected by the mine closure. It becomes even worse when policy intervention is not put in place in time. Little has been done on the effect of the closure of fluorspar mining company in Kenya on livelihoods of households. Given this, the study investigated how the closure of mining companies has affected livelihoods, strategies adopted and gender relations among households in Kenya. Therefore, the current study shades light and provides information on the consequences of mining closure on livelihood strategies among households within the mining area. This information provides the bridge to an existing knowledge gap on the closure of fluorspar mining company and livelihood strategies among households in Keiyo south sub-county Elgeyo Marakwet County Kenya.

\section{Theoretical Review}

This study adopted the theory of Redefinition of the Situation by William Thomas (1994). According to the theory, human beings start with the way they are, and when they find that they are not comfortable, they change their cognition, their attitude and finally their behaviour. The communities in Keiyo South Sub-County re-orientated themselves to adjust to the new situation by adopting coping strategies. These coping strategies helped them meet their necessities of life, such as capabilities, assets (material and social resources) and activities required for a means of living.

\section{Methodology}

- The study was carried out in Keiyo South Sub County, Elgeyo Marakwet County, Kenya. It is endowed with arable land, waters from River Kerio and Fluorspar at Kimwarer which had been closed. Mining of fluorite by the Kenya Fluorspar Company was the largest industry in the former district before its closure. This research adopted the use of pragmatist design as it allows for a combination of both qualitative and quantitative strategies within various phases of research procedure. This paradigm was considered appropriate for this study since the research was anchored on both qualitative and quantitative techniques.

- This study employed the use of a mixed-methods approach. The choice of mixed methods research in this study allows the triangulation. Triangulation allows one to identify aspects of a phenomenon more accurately by approaching it from different vantage 
points using different methods and techniques. The study targeted two wards Soy North with 479 households' heads and Soy South with 367 households' heads sparsely populated.

- The study used $30 \%$ of the target population to derive the sample size of 254 . The researcher purposively selected two wards from the six wards in Keiyo South Sub-county. Cluster sampling was used to select the villages from the two selected wards forming 31 clusters. Proportionate sampling was used to get the number of households to be selected from each cluster. A simple random sampling was used by researcher to select households for study from each cluster giving equal chances of being selected. Further, simple random sampling was used to select the household's heads about the respective number in each cluster.

- The study used survey interviews key informants' interview, focus group discussion (FGDs) and direct observation as the main method of data collection. The collected data was analyzed using both quantitative and qualitative methods. Quantitative analysis entailed the use of descriptive statistics, such as percentages and frequency distribution tables. The qualitative analysis involved identifying major themes emerging from the data collected and relating them to the research objectives. The thematic analysis emphasizes pinpoints, examines and records the themes within the collected data. Qualitative data was presented by the use of themes denoted by narrations and tabulations on responses in verbal form and pictures found in the area of study.

- The researcher sought permission from the respondents and the key informants just before embarking on the interview. This was achieved through informed consent to participants. The researcher also kept the information given with confidentiality of which the respondents did not feel threatened. Consent for household members participating in the study was sought verbally during data collection. The results of the study were provided to relevant authorities and the interested participants.

\section{Findings}

The objective of this study was to analyze the livelihood strategies adopted by Keiyo South Sub-County communities who had benefited from fluorspar mining company after its closure. This was done in order to understand how the communities cope up with the effect of the closure of the mining company.

\section{Meeting the Household Economic Needs after the Closure of the Mining Company}

The study sought to find out how the respondents met their economic needs after the closure of mining company. Table 1 presents the study results.
Table 1. Meeting the household economic needs after the closure of the mining company

\begin{tabular}{ccc}
\hline & Frequency & Percentage \\
\hline Farming & 133 & 64.9 \\
Self-employment & 27 & 13.2 \\
Formal employment & 45 & 21.9 \\
Total & $\mathbf{2 0 5}$ & $\mathbf{1 0 0}$ \\
\hline
\end{tabular}

The study results in Table 1 showed that the respondents were able to meet their economic needs by resorting to farming evidenced by 133(64.9\%), 27(13.2\%) became self-employed while $45(21.9 \%)$ were employed. This implied that after the closure of the mining company, the households adopted other livelihood strategies to sustain their livelihood and meet their economic needs. The household diversified their farming such as growing of tomato, millet, maize, beans and groundnuts. This was adopted by the household to reduce food insecurity. This was because agriculture has to generate household incomes and stimulate the growth of productive off-farm activities in rural areas like Keiyo South Sub-County. Achieving agricultural goals need pursuing several strategies. Therefore, other stokeholds to encourage these households in Keiyo South Sub-County to adopt more effective practices, especially the wider use of improved varieties, fertilizer, disease and pest control, pricing policies, and marketing policies and institutions and the extension services can be the main instrument in obtaining much higher yields through known techniques. Another livelihood strategy adopted by households in Keiyo South Sub-County was charcoal burning to earn and income. The households reduced food consumption patterns from three meals a day to two, and some cases were one. After reduced income, some household changed the type of school, changed health sources and reducing recreational activities. Maiangwa et al. [9] who asserts that after losing of current source of income the households would adopt low-risk, immediate and low-return agricultural and other income-generating strategies.

In Keiyo South Sub-County communities practiced small scale farming. Some households have been employed in the civil service, which is an important income-generating activity besides casual and contractual jobs. Moreover, a number of people are employed by the rural access roads programme. For people who want casual labour, opportunities exist, for example, fencing, weeding, harvesting, and constructing a hut, which is paid per day's work (or predetermined sum of money). In monetary terms, these casual jobs and local contracts are readily available opportunities. Some people own transportation business (public service vehicles) and boda boda services. Others are in self-employment, such as small kiosks, shops and selling honey. The study findings further concurred with Mukangai [10] who noted that maize and other grains, should be re-organized and accelerated to generate the new, high yielding varieties that are essential to keep pace with consumption. In Keiyo South Sub-County communities practiced small scale farming. 
Table 2. Cross classifications of Adaptive Strategies against Closure Effect

\begin{tabular}{|c|c|c|c|c|c|}
\hline & & \multicolumn{2}{|c|}{ Closure impact } & \multirow{3}{*}{$\begin{array}{c}\text { Total } \\
133\end{array}$} & \multirow{6}{*}{$\begin{array}{l}\text { Pearson Chi-Square test } \\
\qquad \begin{array}{c}\chi^{2}=39.462 \mathrm{df}=2 \\
\mathrm{p}=0.00\end{array}\end{array}$} \\
\hline & & Yes & No & & \\
\hline \multirow{3}{*}{ Adaptive Strategies } & Farming & 123 & 10 & & \\
\hline & Self-employment & 16 & 11 & 27 & \\
\hline & Formal employment & 24 & 21 & 45 & \\
\hline & & 163 & 42 & 205 & \\
\hline
\end{tabular}

The results in table 2 above shows that majority of the respondents agreed to farming as the utmost adoptive strategy after losing their employment at Fluorspar miming company. Further the results indicate a 2 observed of 39.462 with a $p$ value $=0.00$ and since in this case $\mathrm{p}=0.000<\alpha=0.05$, this implies that there is significant relationship between adaptive strategies and closure of Fluorspar mining company.

\section{Livestock Keeping}

A 52 older adult reported that;

"After the closure of fluorspar mining company and losing jobs, we opted for livestock keeping to sustain our household needs for example school fees for our children, health expense and community engagement for example ceremonies."

This gave an impression that after the closure of fluorspar mining company households had no option but to come up with alternative strategies to sustain their livelihood. The region is ASAL; therefore, livestock keeping becomes an adaptive measure. The main types of livestock reared in this region include cattle, sheep, goats, poultry, rabbits, pigs, donkeys, and bees keeping. The milk income level in the valley is considerably lower than that of the bluff and the highlands.

The study findings agree with Mwacharo and Drucker [11] who noted that the reasons for keeping cattle is to help in adaptive way of live. In addition to the traditional short-term coping mechanisms, the long-term adaptation strategies used include diversification of livelihood sources; livestock mobility to track forage and water resources; diversification of herd composition to benefit from the varied drought and disease tolerance, as well as fecundity of diverse livestock species; and sending children to school for formal education as a long term investment expected to pay back through income from employment. Policies and development interventions that reduce risks, diminish livelihood constraints, and expand opportunities for increased household resilience to drought are critical complements to the existing pastoral strategies.

The residents' practised poultry farming which was local chicken under free-range management system with minimum feed supplement and moderate housing structures. However, marketing is a major constraint in the commercial poultry sector whereby farmers fail to get good returns to sustain the enterprise and the households due to long distance to competitive markets. Eldoret town and hotels in Iten town are the main market outlets for poultry and products from the region. The pig keeping was not popular in the region due to poor management skills and market constraints. The few animals kept are by the institutions in the area. The pigs kept are crossbreed Landrace and Large White. There is no group in the area that is seriously involved in value addition of honey except the Keiyo South Sub-County Development Authority (KVDA). KVDA served a limited area in the valley, and this was the reason why most of the bee-keepers sold their honey in crude or semi-crude form.

A minority of households in the lowlands sell honey. Most households use it for home consumption, for medicinal purposes to make a local honey brew, and as a delicacy. Honey processing was done by Rokocho honey refinery centre owned by the KVDA. The bee-keepers are also embracing modern methods of beekeeping, such as the use of the KTBH. Cattle production activities in Keiyo are per the three distinct topographical features, namely, the highlands, the escarpment, and the Keiyo South Sub-County. This was due to differences in altitude and rainfall amounts.

A group of community members noted that;

"KVDA has provided us with alternative source livelihood after the closure of the mining company by proving us beehives that we keep until it's ready for harvesting. They also come into harvest honey and pay us our dues."

From the above sentiments, it is evident that KVDA has provided an alternative livelihood strategy to households in Keiyo South Sub-County in terms of generating income through the sale of honey.

The KVDA is running several projects which have employed many people. These projects include Arror multipurpose project, mango processing plant, honey processing plant, lower Turkwel irrigation, greenhouse technology and meat processing.

Introduction of greenhouse technology and promotion of aquaculture as an alternative source to food security by KVDA has boosted livelihood among the residents because they can buy subside food from KVDA.

KVDA supported farm forestry through raising and sale of 10 million assorted tree seedlings to institutions, 
individual farmers and Non-Governmental Organizations (NGOs) for planting within Cherangany and other catchments. Increase in land under irrigation by 500 ha. In existing irrigation projects at Tot, Arror and Ptokou/Sangat to improve food security in the region. Production of 6,000 beehives for community empowerment by improving the quality of honey produced in the region. Construction of 10 (ten) small dams and 90 (ninety) water pans spread within the Keiyo South Sub-County region. Establishment of three additional community empowerment projects, i.e. fish farming in Weiwei, greenhouses in Kerio Roses and Lodwar. Establishment of Livestock Improvement Programme in Chemeron, Baringo County.

KVDA has also rolled out seed nursery project the area that encompasses different varieties of fruits seedlings such as pawpaw, bananas, mangoes among others. These projects have created self-employment, especially to the youths.

\section{Alternative Employment Opportunities}

One of the youths noted that:

"After the closure of fluorspar company, we had no option but to look for employment either formal or self-employment to sustain our livelihood."

This gives the impression that after the closure of the mining company, people had to look for coping strategies to sustain their lives. They look for employment elsewhere and some practice self-employment. Majority of households in the study area are poor; there was a need to achieve economic growth through the use of their products such as self-employment after the closure of the mining company. Failure of the fluorspar mining company to employ after its closure severely handicaps the community economic effort. Therefore, low-income groups are numerous in the study area, hence can create surpluses in highly productive sectors, and then use those surpluses to alleviate their poverty utilizing welfare and relief payments. The households adopted this coping strategy with the need to protect and enhance the assets and income streams.

The study findings concur with Clemens and Wither [12] who found that binding minimum wage increases had significant, negative effects on the employment and income growth of targeted workers.

One of the landscaping experts reported that;

"After the closure of fluorspar mining company, I used my learned skills of landscaping in other parts where I could get earning to feed my family."

This implies that the personal skills and social networks can provide employment, safety nets in times of distress, and routes to savings and remittances used for investment purposes when the formal employment sectors do not help anymore. There was a need, therefore by the household to find ways of assisting the households to increase the range and quality of their productive opportunities and livelihood choices. The creation of productive employment opportunities is one of the most serious challenges facing households in Keiyo. Therefore, they had to come up with self-employment strategy. A central component of the greater efforts towards economic growth, poverty reduction, and increased employment is the strategy for the balanced development of rural areas. Improved productivity and output in self-employment which is essential for overall economic growth is closely linked to services and inputs provided from accessible urban areas.

\section{Agricultural Activities}

One of the small-scale farmers reported that; "We had no option after the closure of the fluorspar company, but to actively participate in agricultural activities in able to cater for our daily needs."

This shows that agriculture was the largest source of gainful employment among the majority of households after the closure of fluorspar mining company. This is central to the economic development of the households and requires a long-term strategy for employment creation and transformation of the economy. Agricultural performance is crucial for households because it provides vital ingredients for economic transformation, such as demand, foreign exchange, raw materials, food, and labour. As part of their diversified livelihood strategies, nearly all households in Keiyo are engaged in some crop production. Farming is the basis of life for most people, although the degree to which they depended upon agriculture varied across the household capability. Furthermore, the types of crops that can be grown, the amounts that can be produced, and the use to which they are put vary in the three ecological zones.

The study concurs with Saha and Bahal [13] who noted that nearly two third of the farmers participated in different non-farm activities. About 53 per cent of the diversifiers were successful and 47 per cent were unsuccessful in their diversified activities. Nearly 41 per cent of the successful diversifiers had moderately high success and only 13.10 per cent were under high success category. Some of the households had highly diversified livelihood, which included farming, no farming and migration. However, this highly diversified nature mainly scattered under low success group. Despite the vast potentiality to diversify the livelihood towards farm and non- farm activities in the study area, there were problems such as negative perception of the community, outdated method of production, lack of improved technology and skills, lack of business start- up budget and absence of wide market for the non-farm output.

One of the farmers reported that;

"The main crop being planted in the maize, which is 
the staple food."

The staple food in the study area is maize, which has been grown in the area. Maize tends to be the staple crop for people in the study area. The residents opted for growing maize because they are less susceptible to damage from crop pests, such as weaverbirds, than are millet and sorghum.

Besides, another respondent noted that;

"The reason for planting maize here is that it requires less labour during planting, weeding, harvest, and processing than those other grains; it is a labour-saving crop compared to the indigenous grains".

This implies that after the closure of fluorspar mining company, the household opted to plant maize because it was less costly during its production. Also, the crops helped the household in food security. Maize has also acquired a higher monetary value than millet and sorghum, and the Keiyo farmer responded to widening market opportunities. Moreover, maize serves the dual purpose of being a commercial crop as well as being a subsistence crop. Though maize is considered as a food crop, it is a cash crop as well for it is an important money earner for both small-scale and large-scale farmers.

A 50-year-old woman revealed that;

"When the mining company closed, we had to look for alternative means of generating income. As a family, we had to plant millet which is friendly to this environment and widely used to brew Busaa and chang'aa."

This means that people continue to grow millet, especially for use in brewing beer as an alternative source of income to sustain their livelihood. However, older informants routinely stated that they grow much of these millets than they did in the past. The reasons they give for this change in the amount of millet planted centre on the greater amount of work they require and its tedious nature.

Another respondent revealed that;

"Apart from planting maize and millet planting of Irish potatoes was an afterthought due to the prevailing situation in this area after the closure of the mining company."

The study findings mean that Irish potatoes were grown in the area because they are suitable for the climate and soils in the study area. The Irish potatoes are popular in these areas not only because of its commercial value but also since it matures in a shorter period than other available crops. It needs very little labour, and the yields are very high. Finally, potatoes like maize serve the dual purpose of being a commercial as well as a subsistence crop. The distribution between "cash" and "food" crops is often an artificial one imposed by the observer.

Although agriculture is the most important means of making a living for most of the households of the study area, by no means do these activities exhaust the range of possibilities. Households in all the study area try to do other things in addition to growing crops and keeping animals; however, their ability to do so varies. The heading "small-scale income-generating activities" subsumes a variety of possibilities, including casual labour (Kibarua).

\section{Income-Generating Activities}

A group of youths reported that:

"The closure of mining company forced us to look for Kibarua such weeding in farms, collecting fire hoods, transportations, stocking of the hood for charcoal burning and sand harvesting. This has helped to substation ourselves in terms of providing our parents and young families."

This means that after the closure of fluorspar mining company, the youths and other households' members are trying to do other income-generating activities in addition to growing crops and keeping animals to sustain their livelihoods. Therefore, they have opted to small-scale income-generating activities subsumes a variety of possibilities, including casual labour (Kibarua). Kibarua is day labour or piece of work paid either in cash or in goods such as sugar or salt," beer brewing and sale, charcoal burning and sale, craftwork, such as the making of sisal ropes, and the making of decorated calabashes (used for milk) from guards. However, it should be noted that the degree to which households depend upon causal labour for income generation was inversely correlated with elevation. Thus, the average amount of money that household members earned and the degree to which they depended upon casual labour for economic survival was greater in the valley than on the bluff or the highlands.

One of the youths reported that:

"I have resorted to play hide and seek game in the forest of burning charcoal to survive this harsh state of Life after the closure of mining company. Although it is illegal, I try my luck because I have no other option left to sustain my family."

This means that some residents in the study area have opted to illegal means of survival to provide the basic needs in their households. They have resorted to burning and sale of charcoal which is undertaken primarily by males, due to the greater availability of trees. In a normal situation, a person has to possess a license to burn trees to make charcoal; in reality, few people do. As it leaves the valley, the price steadily increases.

A 55year older woman reported that:

"Life had been difficult after the closure of the mining company. The brewing of busaa has enabled me to take my children to school and also my grandchildren. Have been able to feed my family with the earning from the brewing and selling of 


\section{busaa and chang'aa brew."}

From the above statement, its evidence that other income-generating activities adopted by the household members after the closure of the mining company are the brewing of busaa and chang'aa. Although officially proscribed, the brewing and sale of traditional beer (busaa) have since been commercialized as a source of income. Currently, busaa is a substantial source of income, especially for women. This beer is often used to compensate the members of a communal work party, and today, the workers who come to perform labour during critical periods in the agricultural cycle are still rewarded with busaa.

A 57-year-old woman noted that:

"After the closure of fluorspar mining company, my child lost his job, and we were dependent on him. Therefore, I had to look for other means of survival to vent by making craftwork to raise income to feed myself and my grandchildren."

This gives an impression that despite craftwork is limited in the study area, some household's members practice as a source of income. The craft activities being carried out in the study area was making ropes from sisal fibres and calabashes from guards as a minor supplementary source of income. Women mostly did this activity.

One of the businessmen indicated that:

"After the closure of the mining company likely we had some money that enables me to start up a goat business. I buy goats cheaply here at Keiyo South Sub-County and supply them on the highlands, where I sell at higher prices. This has enabled me to provide for my family in terms of medical expenses, school fees and entertainment."

The findings show that households who had made some savings during their term of employment ventured into entrepreneurship. They were able to organize production and were a ready risk in the business. Like people in rural communities elsewhere in the developing world, households in the study area do many different things to survive; they diversify rather than specialize their economic enterprises.

A 32-year-old man reported:

"After the closure of fluorspar mining company, many casual labourers lost their source of livelihood and collecting, and selling of scrap metals become an alternative source of income due to its demand and ready market."

This finding shows that due to closure of mining company, there were unutilized metals and equipment which was sold as craps metals. This becomes a source of income to some of the youths who ventured into scrap metal selling business.

The study findings from focus group discussion revealed that the mining company used to employ numerous unskilled workers who are then trained and developed for mining operations. However, the majority of these workers have not found employment in other industries after mine closure. They have to settle for a severely reduced income through subsistence farming, charcoal burning, boda boda business and livestock keeping. This has led to a considerably lower quality of life. The study findings, therefore, indicated that retrenched mineworkers were reluctant to leave their communities at the mine sites. They prefer rather wait for new owners to take over the mine, which may provide employment and uplift their standards of living.

After the closure the roles of men in the study area changed whereby, they engaged in horticultural produce, milking of cows, selling vegetable along the tarmac road, women performed the formation of merry-go-rounds which were traditionally.

A group community member reported that:

"After the closure of fluorspar mining company, we lost the source of livelihood. Therefore, we had no option but to come up with other means of survival such as subsistence farming, casual employment and some of our household members going to bigger towns to look for formal employment."

The community adopted other means of survival which could sustain their family needs after the sudden closure of the mining company. They resorted to doing subsistence farming where they grew maize, beans, millet, sorghum, sweet potatoes and groundnuts. The farming was done much for food, and the little surplus was sold for income generation.

The subsistence farming could not meet the family needs hence the household members had to look for casual jobs to get the income to pay for expenses such as medical, school fees and contribution to the community ceremonies. They had to look for casual jobs such as sand harvesting, weeding, and collection of firewood for sell, among others.

The community members who participated in FGD noted that:

"Part of KVDA projects is the making of seedlings such as mangoes and avocados that do well in Keiyo South Sub-County. This provided us with other sources of income and employment creation from the production and processing of these fruits.

Concerning community members' responses above, it can be noted that KVDA becomes one of alternative source of livelihood to community members after the sudden closure of mining company. They create employment to some community members to work on their projects such as tree nurseries, beekeeping and irrigation. They also provided community members with training on growing of drought residence crops as well as supplying them with seedlings. 
Furthermore, the household members had to look for self-employment to cope up with the sudden loss of livelihood. They invested in small business such as kiosk, mitumba business, butcheries, groceries and boda boda business. These businesses were carried by a few members of the community to meet the daily needs of their family members and dependents.

Family members with skills and education decided to look for formal jobs in other areas of the country. Some moved to Eldoret town and Iten town in search of formal employment to meet their basic needs and for their family members who were fully dependent on them.

The community members noted:

"Due to sudden loss of livelihood after the closure of the mining company, we had to invest in livestock keeping especially goats and indigenous cows who are adapting well to the weather of ASAL areas. These animals help us in terms of food and income generation. We sell them to send our children to school and meet daily family needs as well as medical expenses."

The above voices show that the community members had to invest in livestock keeping due to the conducive environment for the rearing of goats and indigenous cows. This was an alternative strategy to relief them from dire poverty situation. These animals become a source of income to meet family expenses as well as a source of food. Rearing of these animals doesn't need much production cost because they graze in open land and need few maintenance expenses in terms of deworming and mineral supplements.

Further, the community members practised poultry farming as an alternative source of income. These were mostly the indigenous chicken which required less maintenance cost and was done by women. It was practised for food and sell at local markets such as Kabarnet.

A person's livelihood is comprised of 'the capabilities, assets (material and social) and activities required for a means of living. A livelihood is sustainable when it can cope with and recover from stresses and shocks, and maintain or enhance its capabilities and assets both now and in the future, while not undermining the natural resource base.'

\section{Conclusions and Recommendations}

The study concluded that the mining communities could be able to meet their economic needs by resorting to other activities like diversification of farming, self-employment and seeking employment. Motivations behind these choices can depend on households' characteristics (education, productivity, among others.), on the economic and environmental context (access to markets, access to land, quality of environmental resources, among others) and preferences (profit-maximizing or safety-first approaches, among others.

There is a need for mining companies to develop a contingency plan to mitigate the potential socio-economic consequences, which leads to human suffering due to unexpected mine closure. This will assist in building resilience into the livelihood strategies of mineworkers and their dependents as well as surrounding communities dependent on these mining companies.

\section{REFERENCES}

[1] Assan, J. K., \& Muhammed, A. R. (2018). The impact of mining on farming as a livelihood strategy and its implications for poverty reduction and household well-being in Ghana. International Journal of Development and Sustainability, 7(1), 1-20.

[2] Plumpton, A. J. (Ed.). (2017). Production and Processing of Fine Particles: Proceedings of the International Symposium on the Production and Processing of Fine Particles, Montreal, August 2(2),28-31.

[3] Pierola, M. D., Fernandes, A. M., \& Farole, T. (2015). The role of imports for exporter performance in Peru. The World Bank.

[4] Abrahamsson, L., Nygren, M., Segerstedt, E., \& Loow, J. (2016). Challenges in obtaining a social licence to mine. AusIMM Bulletin, (Dec 2016), 56.

[5] Fleming, D. A., \& Measham, T. G. (2015). Income inequality across Australian regions during.

[6] Andriamasinoro, F., \& Angel, J. M. (2012). Artisanal and small-scale gold mining in Burkina Faso: suggestion of multi-agent methodology as a complementary support in elaborating a policy. Resources Policy, 37(3), 385-396.

[7] Ofosu-Mensah, E. A. (2016). Mining in colonial Ghana: Extractive capitalism and its social benefits in Akyem Abuakwa under Nana Ofori Atta I. Africa Today, 63(1), 23-55.

[8] Mensah E.A.O., (2011) Gold mining and the socio-economic development of Obuasi in Adanse. African Journal of History and Culture, 3(4).54-64.

[9] Maiangwa, M. G., Omolehin, R. A., Adeniji, O. B., \& Mohammed, U. S. (2010). Food insecurity: challenges of agricultural extension in developing countries. Journal of agricultural extension, 14(2).

[10] Mukangai, M. D. (2019). The interplay between state policies and agricultural production in Kakamega, Kenya, 1930-1970. Journal of Economics and sustainable development, 5(4), 104-111.

[11] Mwacharo, J. M., \& Drucker, A. G. (2015). Production objectives and management strategies of livestock keepers in South-East Kenya: Implications for a breeding programme. Tropical Animal Health and Production, 37(8), 635-652.

[12] Clemens, J., \& Wither, M. (2019). The minimum wage and 
the Great Recession: Evidence of effects on the employment and income trajectories of low-skilled workers. Journal of Public Economics, 170, 53-67.
[13] Saha, B., \& Bahal, R. (2016). Livelihood diversification pursued by farmers in West Bengal. Indian Research Journal of Extension Education, 10(2), 1-9. 